\title{
The Histone Demethylase NO66 Induces Glioma Cell Proliferation
}

\author{
QING WANG ${ }^{1}$, PEI Y. LIU ${ }^{2}$, TAO LIU ${ }^{2}$ and QING LAN ${ }^{1}$ \\ ${ }^{1}$ Department of Neurosurgery, the Second Affiliated Hospital of Soochow University, Suzhou, P.R. China; \\ ${ }^{2}$ Children's Cancer Institute Australia, Sydney, Australia
}

\begin{abstract}
Background/Aim: The histone demethylase NO66 regulates gene and protein expression. Epidermal growth factor receptor (EGFR) is a key oncogenic factor for glioblastoma. This study aimed to examine the role of NO66 in glioblastoma. Materials and Methods: The prognostic value of NO66 expression in 263 human glioma tissues and 510 glioblastoma tissues was examined by Kaplan and Meier survival analysis. Immunoblot analysis of EGFR expression, cell proliferation assays and cell cycle analysis were performed in glioblastoma cells after NO66 knockdown. Results: In 263 human glioma tissues, high levels of NO66 expression correlated with advanced disease stage and poor patient prognosis. In 510 glioblastoma tissues, high levels of NO66 expression also predicted poor patient prognosis. NO66 knockdown reduced EGFR expression and cell proliferation in glioblastoma cells. Conclusion: High levels of NO66 in glioma and glioblastoma tissues predict poor patient prognosis, and NO66 is required for EGFR expression and glioblastoma cell proliferation.
\end{abstract}

Glioma is the most common neoplasm of the brain in adults and is one of the deadliest human cancers (1). Despite surgery, chemotherapy and radiation therapy, the median survival time for patients with stage IV glioma, also known as glioblastoma, is approximately 15 to 16 months, and most patients die from this disease within 2 years (1). There is an urgent need for better understanding of glioma tumorigenesis and the identification of novel therapeutic targets.

Histone modification enzymes, such as histone deacetylases, methyltransferases and demethylases, play important roles in the transcription of important oncogenes

Correspondence to: Qing Lan, Director, Department of Neurosurgery, the Second Affiliated Hospital of Soochow University, Suzhou, Jiangsu 215004, PR China. Tel: +86 51267784087, e-mail: szlq006@163.com

Key Words: NO66, glioblastoma, EGFR, cell proliferation, prognosis. and the initiation and progression of various cancers (2-5). Histone deacetylase inhibitors induce the acetylation of histone and non-histone proteins, activate the transcription of tumor suppressor genes, result in glioma cell growth inhibition and apoptosis, and are currently in clinical trials in glioma patients [reviewed in (4)]. Using RNA interference (RNAi) screening technology and orthotopic patient-derived glioblastoma xenograft models, Miller et al. have identified the histone demethylase JMJD6 as a critical regulator of oncogene transcription and glioblastoma cell survival, and confirmed the anticancer efficacy of therapies targeting JMJD6 (6). Using CRISPR-Cas9 approaches in patientderived glioblastoma stem cells to interrogate function of the coding genome, MacLeod et al. have identified the histone methyltransferase DOT1L as an actionable factor important for glioblastoma stem cell growth and temozolomide resistance (7).

The Jumonji C (JmjC)-domain containing histone lysine demethylase NO66, also known as c14orf129, is located at both nucleoli and chromatin, and is highly conserved during evolution (8). As a histone demethylase for monomethylated histone lysine 4 (H3K4me) and lysine 36 (H3K36me), NO66 plays a critical role in blocking osteoblast differentiation and skeletal formation through direct interaction with the osteoblast-specific transcription factor Osterix and inhibition of Osterix-mediated transcriptional activation (9). NO66 also binds the Polycomb repressive complex 2 (PRC2) component PHF19 at stem cell genes during stem cell differentiation, leading to PRC2-mediated trimethylation of histone H3 Lys27 (H3K27), loss of H3K36me3 and transcriptional silencing (10). In addition, NO66 catalyzes histidine hydroxylation of proteins such as 60S ribosomal protein RPL8 $(11,12)$, and thereby modulates protein synthesis.

The role of NO66 in glioma has not been reported. In this study, we have found that high levels of NO66 gene expression in human glioma tissues positively correlate with advanced disease stage and poor survival in a cohort of glioma patients, and high levels of NO66 gene expression in 
human glioblastoma tissues also significantly corelate with poor survival in another independent cohort of glioblastoma patients. In glioblastoma cells, NO66 knockdown reduces the expression of the key glioblastoma oncoprotein epidermal growth factor receptor (EGFR) and results in cell growth inhibition.

\section{Materials and Methods}

Cell culture and transfection. U87 and SF126 human glioblastoma cells were cultured in Dulbecco's modified Eagle's medium (DMEM) supplemented with $10 \%$ fetal bovine serum at $37^{\circ} \mathrm{C}$ with $5 \%$ carbon dioxide. U87 cells were purchased from the American Type Culture Collection (Manassas, VA, USA), and SF126 cells were purchased from the European Collection of Cell Cultures, respectively.

siRNAs transfection. Cells were transfected with $20 \mathrm{nM}$ control siRNA or siRNAs targeting NO66 with Lipofectamine 2000 reagent (Invitrogen, Carlsbad, CA, USA) as described previously. Validated negative control siRNA and siRNAs specifically targeting NO66 were purchased from QIAGEN (Qiagen, Hamburg, Germany). The negative control siRNA did not target any human gene (All Stars Negative Control siRNA, Qiagen). The target sequences of NO66 siRNAs were: 5'-AACCATCTCATCTAGGTACAA-3' for NO66 siRNA-1; and 5'-AAGCAGCTGCGAAGTGTTGTA-3' for NO66 siRNA-2.

$R N A$ extraction and RT-PCR. RNA was extracted from glioblastoma cells, $48 \mathrm{~h}$ after transfection with control siRNA or NO66 siRNAs, with PureLink RNA Mini Kit (Invitrogen). cDNA was synthesized from the RNA samples with M-MLV Reverse Transcriptase (Thermo Fisher Scientific, Waltham, MA, USA), and $\sim 10 \mathrm{ng}$ of the resulting cDNA was used in real-time PCR reactions with SYBR Green PCR Master Mix (Thermo Fisher Scientific) and genespecific forward or reverse primer (Sigma, Sydney, Australia). The real-time PCR reactions consisted of one cycle at $95^{\circ} \mathrm{C}$ for $10 \mathrm{~min}$, followed by 40 cycles at $95^{\circ} \mathrm{C}$ for $15 \mathrm{sec}$ and at $60^{\circ} \mathrm{C}$ for $1 \mathrm{~min}$. The sequences of the primers for PCR amplifications were: 5'CACCATGTACCCTGGCATT-3' (forward) and 5'-ACGGAGT ACTTGCGCTCAG-3' (reverse) for $\beta$-actin; and 5'-GCGAGCCA AAGACTTCATTC-3' (forward) and 5'-GAATTGGAAGCCCGT AAACA-3' (reverse) for NO66.

Protein extraction and immunoblot. Forty-eight h after siRNA transfection, glioblastoma cells were washed with cold phosphate buffered saline and lysed in radioimmunoprecipitation assay buffer ( $150 \mathrm{mM} \mathrm{NaCl}, 1 \% \mathrm{NP}-40,0.5 \%$ sodium deoxycholate, $0.1 \%$ SDS, $50 \mathrm{mM}$ Tris-Cl pH 7.5) with $1 \%$ Protease Inhibitor Cocktail (Sigma) for $30 \mathrm{~min}$ on ice. After centrifugation for $20 \mathrm{~min}$ at $13,000 \times \mathrm{g}$ at $4^{\circ} \mathrm{C}$, the supernatants were recovered and protein concentration was determined by the Bicinchoninic Acid protein assay kit (Thermo Fisher Scientific). Thirty $\mu \mathrm{g}$ of total protein was separated by sodium dodecyl sulfate-polyacrylamide gel electrophoresis and then transferred to membrane, followed by blocking for one $\mathrm{h}$ with $10 \%$ skim milk. Membranes were probed with rabbit anti-NO66 antibody (1:2000, Abcam, Cambridge, MA, USA), mouse anti-EGFR antibody (1:500, Santa Cruz Biotech, Santa Cruz, CA, USA), rabbit anti-c-Myc antibody (1:1000, Abcam), and mouse anti-actin antibody (1:10000, Sigma), followed by horseradish peroxidaseconjugated anti-rabbit or anti-mouse antibodies (1:10000, Merck, Kenilworth, NJ, USA). Protein expression was imaged using SuperSignal reagents (Thermo Scientific).

Alamar blue assays. Cell proliferation was examined with Alamar blue assays. Briefly, glioblastoma cells were plated into 96-well plates, transfected with control siRNA, NO66 siRNA-1 or NO66 siRNA-2. Ninety-six $h$ after siRNA transfection, cells were incubated with $20 \mu \mathrm{l}$ per well of Alamar blue reagent (Invitrogen) for $6 \mathrm{~h}$, and then plates were read on a microplate reader at 570/595 $\mathrm{nm}$. Results were analysed by calculating the optical density absorbance and expressed as percentage change in cell numbers, as we described previously $(13,14)$.

Cell cycle analysis. U87 and SF126 glioblastoma cells were transfected with control siRNA, NO66 siRNA-1 or NO66 siRNA2. Ninety-six hours later, the cells were harvested, pelleted, washed and fixed drop-wise in ice-cold $70 \%$ ethanol. Cells were then stained with propidium iodide (Sigma) and DNAse-free RNAse (Sigma), and propidium iodide staining in the cells was examined by FACSCallibur Flow Cytometer (BD Biosciences, Franklin Lakes, NJ, USA). The percentage of cells at each phase of the cell cycle was analysed using FlowJo software (Tree Star Incorporated, Ashland, OR, USA).

Patient tumor sample analysis. NO66 mRNA expression was examined using the publicly available Glioma - French dataset (Tumor Glioma - French - 284 - MAS5.0 - u133p2) $(15,16)$ and Glioblastoma - The Cancer Genome Atlas (TCGA) dataset (Tumor Glioblastoma-TCGA-540-MAS5.0-u133a) (17), both downloaded from the R2: Genomics Analysis and Visualization Platform (18). Only 263 out of 284 samples in the Glioma - French dataset and 510 out of 540 samples in the Glioblastoma - TCGA dataset were used for analysis, as information on patient prognosis for the other samples was not available. Correlation between NO66 gene expression and disease stage (stages I, II and III versus stage IV) in the 263 glioma tumor tissues was analysed with un-paired Student's $t$-test. Probability of survival was investigated according to NO66 gene expression levels in the 263 glioma and 510 glioblastoma tissues, using the Kaplan-Meier method and the two-sided log-rank test (19).

Statistical analysis. Results are expressed as the mean and standard errors. The paired Student's $t$-test and one-way ANOVA were used to determine statistical significance between two groups or more than two groups respectively. A $p$-value of $<0.05$ was considered statistically significant.

\section{Results}

High levels of NO66 expression in glioma tissues correlate with advanced disease stage and poor patient prognosis. To assess the clinical relevance of the histone demethylase NO66 in glioma, we examined NO66 gene expression in human glioma and glioblastoma tissues in the publicly available Glioma - French dataset (Tumor Glioma - French - 284 MAS5.0 - u133p2) $(15,16)$ and Glioblastoma - TCGA dataset (17), both downloaded from the R2: Genomics Analysis and Visualization Platform (18). Un-paired Student's $t$-test showed 
that NO66 gene expression was significantly higher in 150 stage IV, compared with 113 Stage I, II and III, glioma tissues in the Glioma - French dataset (Figure 1A). Importantly, Kaplan-Meier survival analysis showed that high NO66 gene expression levels were associated with poor patient prognosis in the 263 glioma tissues of the Glioma - French dataset and the 510 glioblastoma tissues of the Glioblastoma - TCGA dataset (Figure 1B). Taken together, the data suggest that high levels of NO66 expression in human tumor tissues correlate with advanced glioma stage and predict poor prognosis in glioma and glioblastoma patients.

NO66 mRNA and protein are effectively knocked down by two independent siRNAs. We next transfected U87 and SF126 glioblastoma cells with control siRNA, NO66 siRNA-1 or NO66 siRNA-2. The two NO66 siRNAs targeted different regions of the NO66 mRNA. As shown in Figure 2A, RT-PCR analysis confirmed that transfection with the two independent NO66 siRNAs efficiently knocked down NO66 mRNA expression. Consistent with these data, immunoblot analysis demonstrated that transfection with NO66 siRNA-1 or NO66 siRNA-2 efficiently knocked down NO66 protein expression (Figure 2B). The data therefore confirm the efficacy of the two independent NO66 siRNAs.

NO66 is required for EGFR and $c-M y c$ expression in glioblastoma cells. EGFR is a key glioblastoma oncoprotein (20) and c-Myc also plays a critical role in glioblastoma tumorigenesis (21). We examined whether NO66 modulated EGFR and c-Myc protein expression. As shown in Figure 3, immunoblot analysis demonstrated that knocking down NO66 with the two independent siRNAs both effectively reduced EGFR and c-Myc protein expression in U87 and SF126 cells. The data confirm that NO66 is required for EGFR and c-Myc oncoprotein expression in glioblastoma cells.

NO66 promotes glioblastoma cell proliferation. To understand whether NO66 plays a role in glioblastoma cell proliferation, we transfected U87 and SF126 glioblastoma cells with control siRNA, NO66 siRNA-1 or NO66 siRNA2. Alamar blue assays showed that transfection with the two independent NO66 siRNAs, compared with the control siRNA, significantly reduced the number of glioblastoma cells (Figure 4A).

We next transfected U87 and SF126 cells with control siRNA, NO66 siRNA-1 or NO66 siRNA-2 for $72 \mathrm{~h}$, followed by staining with propidium iodide. Flow cytometry analysis showed that knocking down NO66 with NO66 siRNAs significantly decreased the percentage of cells at the $S$ phase (Figure 4B). The data demonstrate that NO66 expression in glioblastoma cells induces glioblastoma cell proliferation.
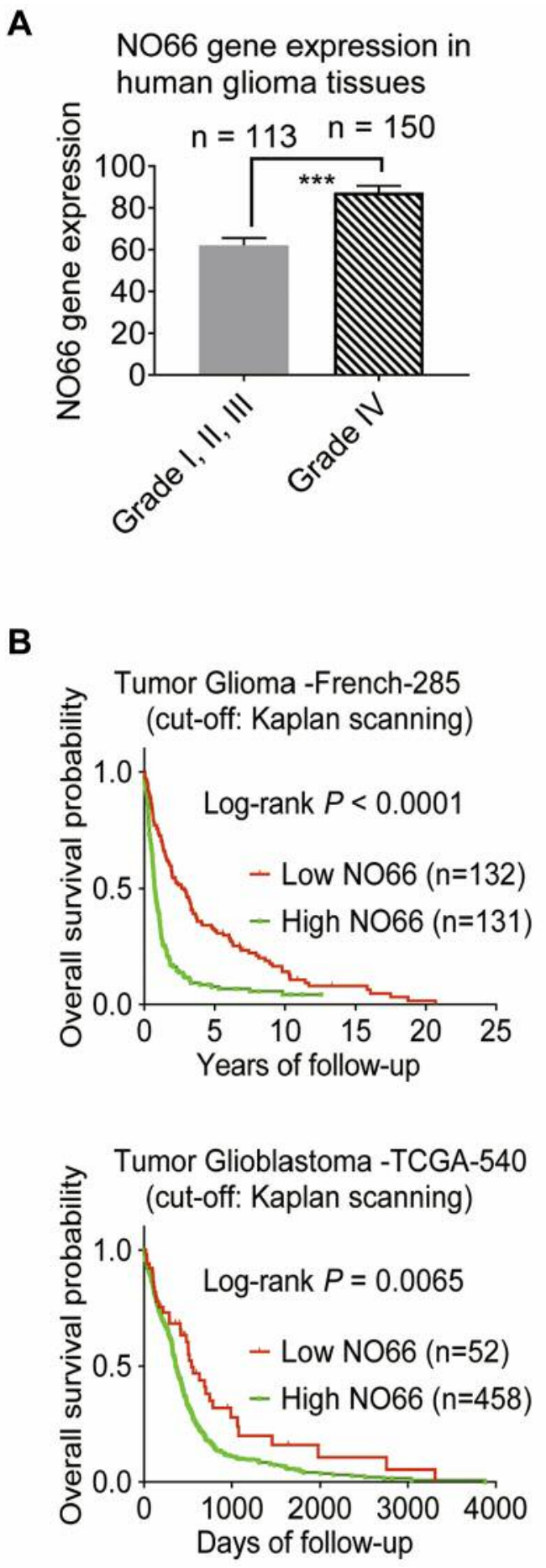

Figure 1. High levels of NO66 expression in glioma tissues correlate with advanced disease stage and poor patient prognosis. Correlation between NO66 gene expression and disease stage (stages I, II and III versus stage $I V)$ in the 263 glioma tumor tissues in the publicly available Glioma French dataset was analysed with paired Student's t-test (A). KaplanMeier curves showed the overall survival probability of patients according to NO66 mRNA expression levels in the 263 glioma tissues in the publicly available Glioma - French dataset and 510 glioblastoma tissues in the publicly available Glioblastoma - TCGA dataset (B). 
A

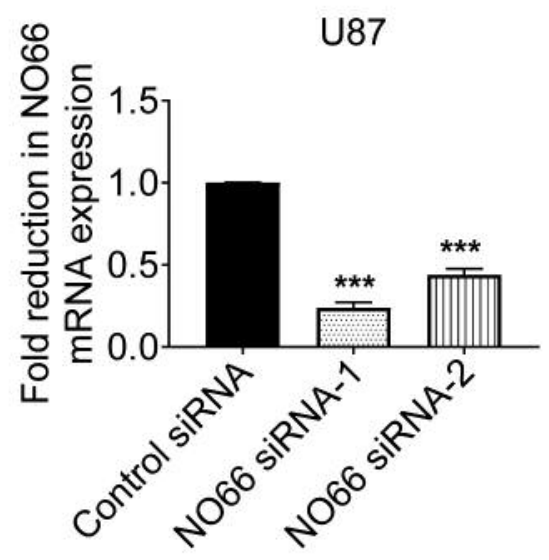

B
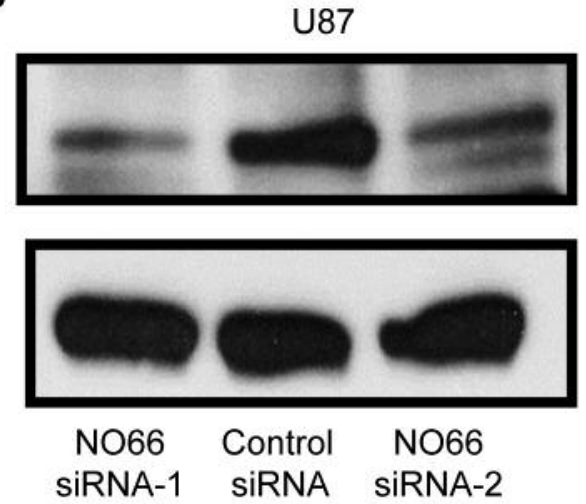

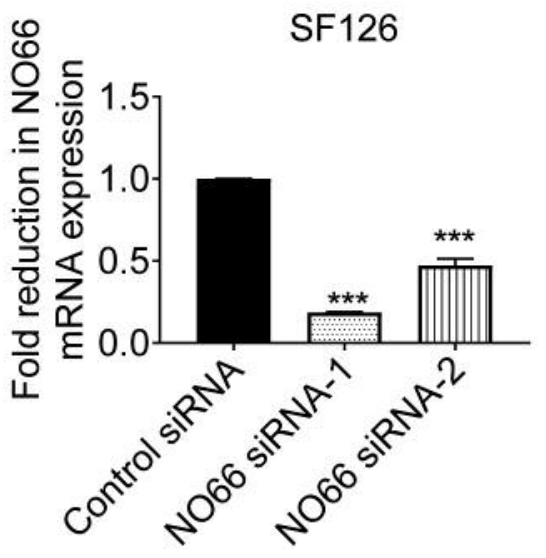

SF126

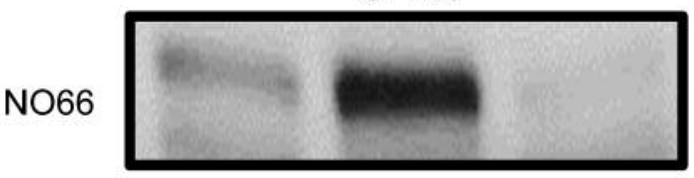

Actin

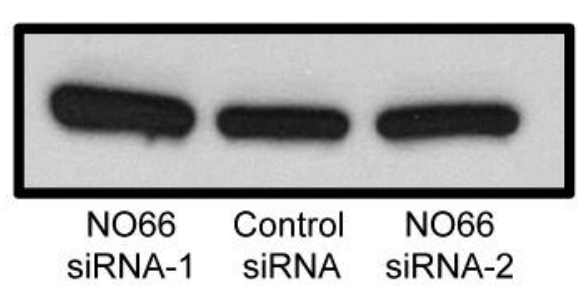

Figure 2. NO66 mRNA and protein are effectively knocked down by two independent siRNAs. U87 and SF126 cells were transfected with control siRNA, NO66 siRNA-1 or NO66 siRNA-2 and incubated for 48 h. RNA was extracted from the cells for RT-PCR analysis of NO66 mRNA expression (A), and protein was extracted from the cells for immunoblot analysis of NO66 protein expression (B). Error bars represent standard error. * $p<0.05$, $* * p<0.01$, and $* * * p<0.001$.

\section{Discussion}

The histone demethylase NO66 binds transcription factors, such as Osterix and PHF19, targets H3K4me, H3K27me3, $\mathrm{H} 3 \mathrm{~K} 36 \mathrm{me} 3$ and $\mathrm{H} 3 \mathrm{~K} 36 \mathrm{me}$, and thereby regulates gene transcription $(9,10,22)$. By catalyzing histidine hydroxylation of the 60S ribosomal protein RPL8, NO66 post-transcriptionally modulates protein synthesis $(11,12)$. Through regulating gene and protein expression, NO66 plays an important role in cellular functions.

NO66 is selectively expressed in human colorectal cancer tissues, and high NO66 expression in human colorectal cancer tissues is associated with poor patient prognosis and metastasis, including lymphatic duct invasion, venous invasion and lymph node metastasis (23). NO66 is also highly expressed in human prostate cancer tissues, and high levels of NO66 expression in prostate cancer tissues predict poor patient prognosis (22).
The role of NO66 in glioma has not been reported. In this study, we have found that high levels of NO66 gene expression in human glioma tissues positively correlate with advanced disease stage and poor survival in a cohort of glioma patients, and high levels of NO66 gene expression in human glioblastoma tissues also significantly corelate with poor survival in another independent cohort of glioblastoma patients. The data confirms NO66 as a marker for poor prognosis in glioma and glioblastoma patients.

NO66 has most recently been reported to activate the expression of the pro-oncogenic protein $\beta$-catenin and cyclin D1, the cell proliferation and survival protein MCL1, the invasionassociated proteins IGFBP5 and MMP3, and the epigenetic modifier KMT2A in androgen-independent prostate cancer cells (22). NO66 thereby promotes prostate cancer cell proliferation in vitro and prostate cancer progression in mice (22). In addition, NO66 induces colorectal cancer cell proliferation and migration, although the mechanism is not clear (23). 
U87

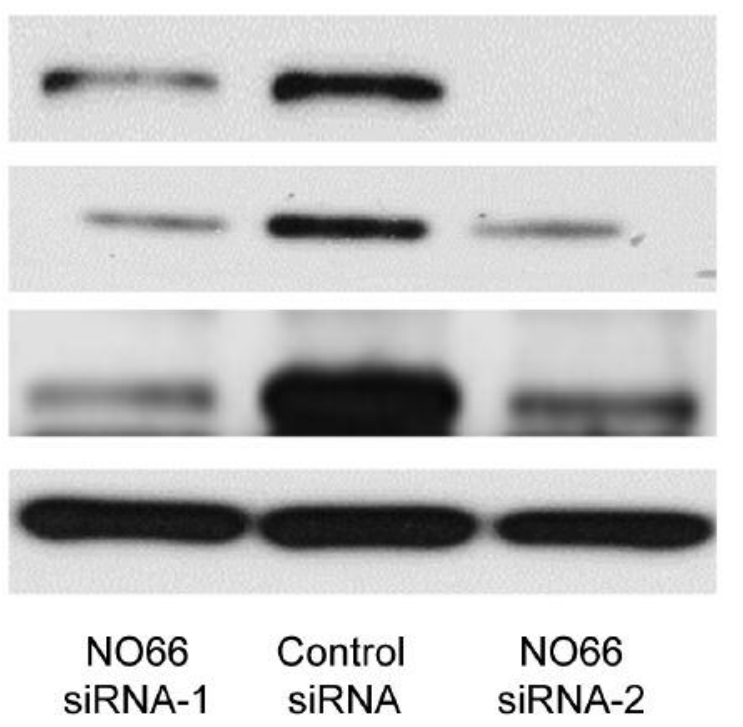

SF126

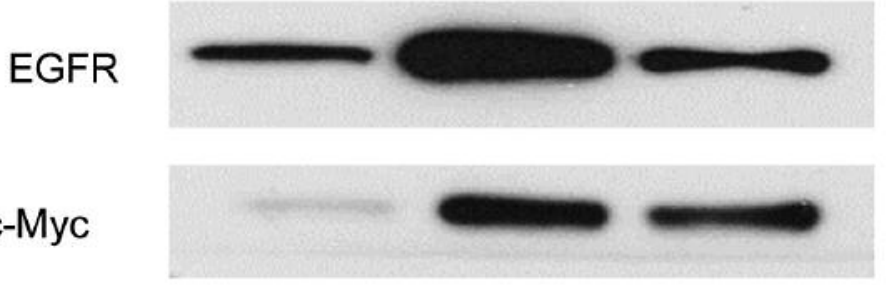

NO66

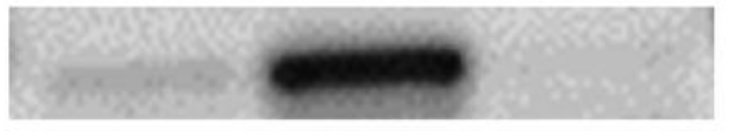

Actin

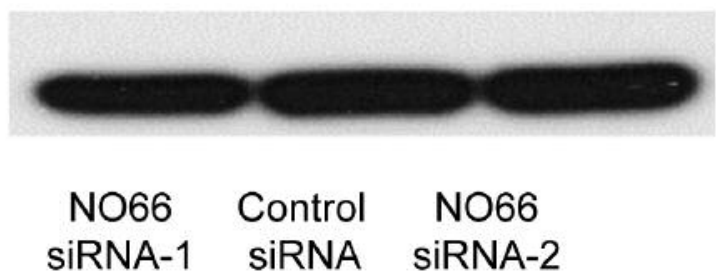

Figure 3. NO66 is required for EGFR protein expression. U87 and SF126 cells were transfected with control siRNA, NO66 siRNA-1 or NO66 siRNA2 and incubated for 48 h. Protein was extracted from the cells for immunoblot analysis of EGFR and c-Myc protein expression.

EGFR activates the phosphoinositide-3-kinase/Akt (PI3K/AKT) pathway as well as the Ras/RAF/mitogenactivated protein kinase/extracellular signal-regulated (Ras/ RAF/MAPK/ERK) pathway, blocks glioblastoma tumorinitiating cell differentiation, induces glioblastoma tumorinitiating cell tumorigenicity, and induces glioblastoma cell proliferation and survival $(20,24)$. In glioblastoma cells, silencing of the p53 and PTEN tumor suppressors leads to c-Myc oncoprotein functional activation, and c-Myc blocks glioblastoma cell differentiation, enhances self-renewal capacity of neural stem cells and glioblastoma tumorinitiating cells, and induces glioblastoma cell proliferation and tumorigenesis $(21,25)$. While the role of NO66 in glioblastoma has not been reported, in this study, we have found that NO66 gene knockdown with two independent siRNAs significantly reduces EGFR and c-Myc protein but not mRNA expression, and down-regulates glioblastoma cell proliferation. As NO66 is known to regulate protein synthesis through catalyzing histidine hydroxylation of the $60 \mathrm{~S}$ ribosomal protein RPL8 $(11,12)$, NO66 is likely to upregulate EGFR and c-Myc protein expression through modulating protein synthesis, and induces glioblastoma cell proliferation through regulating EGFR and c-Myc protein expression. Our data therefore identify the histone demethylase NO66 as an oncogenic factor and a therapeutic target for glioblastoma.

\section{Conclusion}

Histone modification proteins are emerging as critical regulators of tumorigenesis and as important therapeutic targets. The histone demethylase NO66 has most recently been shown to play an oncogenic role in prostate and colorectal cancers. In the currently study, we have demonstrated that high levels of NO66 expression in human glioma tissues correlate with advanced disease stage, and high levels of NO66 expression in glioma and glioblastoma tissues predict poor patient prognosis. Additionally, NO66 is required for EGFR and c-Myc oncoprotein expression, and induces glioblastoma cell proliferation. Our data therefore confirm the oncogenic role of the histone demethylase NO66 in glioblastoma, and identify NO66 as a therapeutic target for glioblastoma.

\section{Conflicts of Interest}

The Authors have no conflicts of interest to declare in regard to this study.

\section{Authors' Contributions}

QW performed the experiments, analyzed the data and wrote the first draft of the article. TL and QL conceptualized the project, supervised the experiments and revised the article. 
A

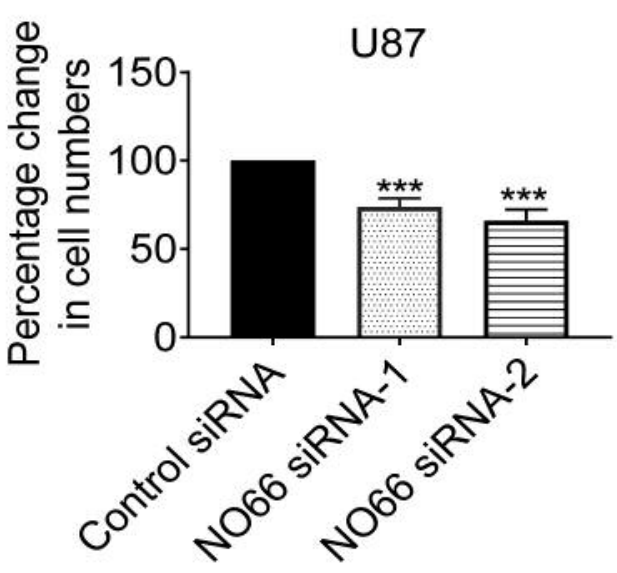

B

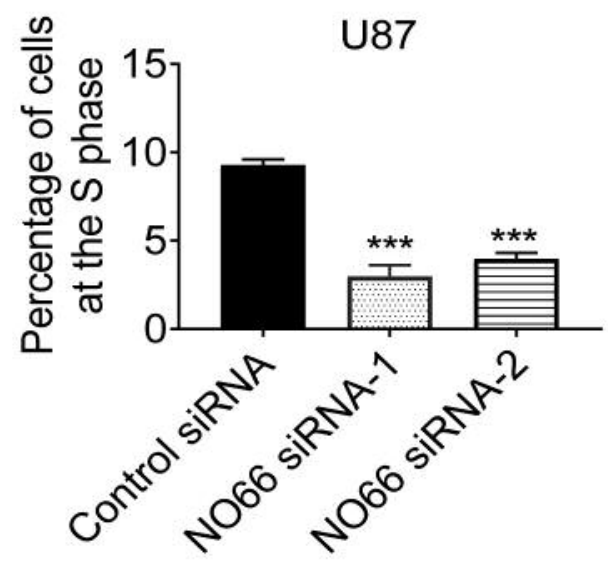

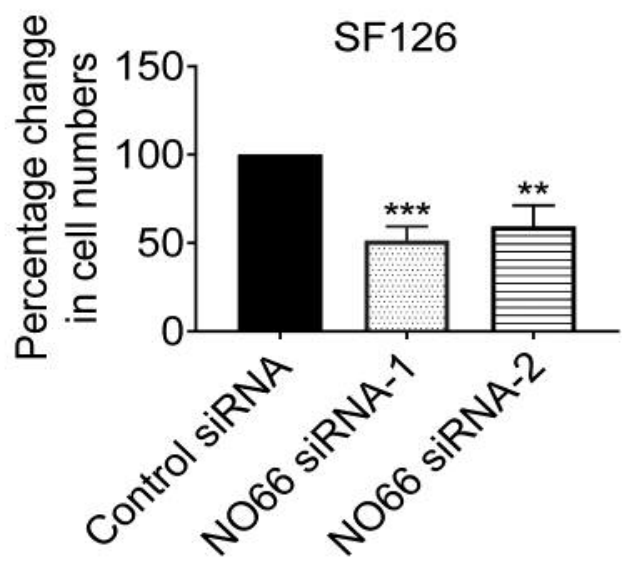

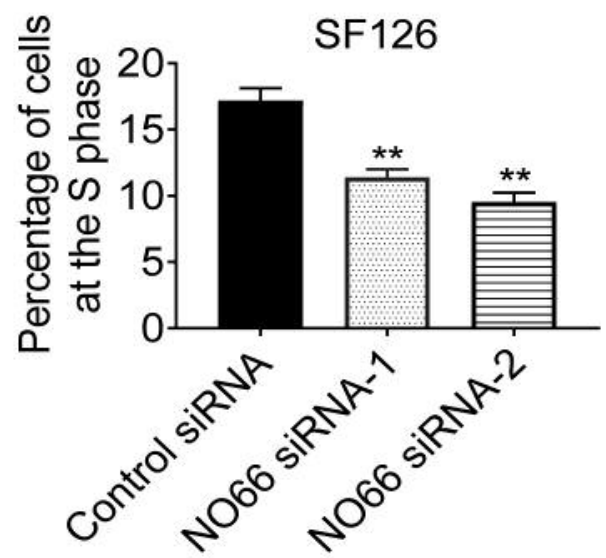

Figure 4. NO66 promotes glioblastoma cell proliferation. U87 and SF126 glioblastoma cells were transfected with control siRNA, NO66 siRNA-1 or NO66 siRNA-2 and incubated for 96 h. Cells were then stained with Alamar blue for Alamar blue assays of the number of viable cells (A), or stained with propidium iodide for flow cytometry analysis of the cell cycle (B). For Alamar blue assays, results were expressed as percentage change of the number of viable cells, relative to control siRNA-transfected samples (A). For the flow cytometry analysis of the cell cycle, the percentage of cells at each phase of the cell cycle was calculated (B). Error bars represent standard error. ** and *** indicate $p<0.01$ and 0.001 respectively.

\section{Acknowledgements}

The Authors were supported by Key Disciplines of Jiangsu Provincial Department of Health and the National Health and Medical Research Council Australia.

\section{References}

1 Bi WL and Beroukhim R: Beating the odds: Extreme long-term survival with glioblastoma. Neuro Oncol 16(9): 1159-1160, 2014. PMID: 25096192. DOI: 10.1093/neuonc/nou 166

2 Wong M, Sun Y, Xi Z, Milazzo G, Poulos RC, Bartenhagen C, Bell JL, Mayoh C, Ho N, Tee AE, Chen X, Li Y, Ciaccio R, Liu PY, Jiang CC, Lan Q, Jayatilleke N, Cheung BB, Haber M, Norris MD, Zhang XD, Marshall GM, Wang JY, Huttelmaier S, Fischer M, Wong JWH, Xu H, Perini G, Dong Q, George RE and Liu T: Jmjd6 is a tumorigenic factor and therapeutic target in neuroblastoma. Nat Commun 10(1): 3319, 2019. PMID: 31346162. DOI: 10.1038/s41467-019-11132-w

3 Wong M, Tee AE, Milazzo G, Bell JL, Poulos RC, Atmadibrata B, Sun Y, Jing D, Ho N, Ling D, Liu PY, Zhang XD, Huttelmaier S, Wong JW, Wang J, Polly P, Perini G, Scarlett CJ and Liu T: The histone methyltransferase dot11 promotes neuroblastoma by regulating gene transcription. Cancer Res 77(9): 2522-2533, 2017. PMID: 28209620. DOI: 10.1158/0008-5472.can-16-1663

4 Lee P, Murphy B, Miller R, Menon V, Banik NL, Giglio P, Lindhorst SM, Varma AK, Vandergrift WA, 3rd, Patel SJ and Das A: Mechanisms and clinical significance of histone deacetylase inhibitors: Epigenetic glioblastoma therapy. Anticancer Res 35(2): 615-625, 2015. PMID: 25667438.

5 Sun Y, Atmadibrata B, Yu D, Wong M, Liu B, Ho N, Ling D, Tee AE, Wang J, Mungrue IN, Liu PY and Liu T: Upregulation of lyar induces neuroblastoma cell proliferation and survival. Cell Death Differ 24(9): 1645-1654, 2017. PMID: 28686580. DOI: $10.1038 / \mathrm{cdd} .2017 .98$ 
6 Miller TE, Liau BB, Wallace LC, Morton AR, Xie Q, Dixit D, Factor DC, Kim LJY, Morrow JJ, Wu Q, Mack SC, Hubert CG, Gillespie SM, Flavahan WA, Hoffmann T, Thummalapalli R, Hemann MT, Paddison PJ, Horbinski CM, Zuber J, Scacheri PC, Bernstein BE, Tesar PJ and Rich JN: Transcription elongation factors represent in vivo cancer dependencies in glioblastoma. Nature 547(7663): 355-359, 2017. PMID: 28678782. DOI: $10.1038 /$ nature 23000

7 MacLeod G, Bozek DA, Rajakulendran N, Monteiro V, Ahmadi M, Steinhart Z, Kushida MM, Yu H, Coutinho FJ, Cavalli FMG, Restall I, Hao X, Hart T, Luchman HA, Weiss S, Dirks PB and Angers S: Genome-wide crispr-cas9 screens expose genetic vulnerabilities and mechanisms of temozolomide sensitivity in glioblastoma stem cells. Cell Rep 27(3): 971-986.e979, 2019. PMID: 30995489. DOI: 10.1016/j.celrep.2019.03.047

8 Eilbracht J, Reichenzeller M, Hergt M, Schnolzer M, Heid H, Stohr M, Franke WW and Schmidt-Zachmann MS: No66, a highly conserved dual location protein in the nucleolus and in a special type of synchronously replicating chromatin. Mol Biol Cell 15(4): 1816-1832, 2004. PMID: 14742713. DOI: 10.1091/ mbc.e03-08-0623

9 Sinha KM, Yasuda H, Coombes MM, Dent SY and de Crombrugghe B: Regulation of the osteoblast-specific transcription factor osterix by no66, a jumonji family histone demethylase. Embo j 29(1): 68-79, 2010. PMID: 19927124. DOI: 10.1038/emboj.2009.332

10 Brien GL, Gambero G, O'Connell DJ, Jerman E, Turner SA, Egan CM, Dunne EJ, Jurgens MC, Wynne K, Piao L, Lohan AJ, Ferguson N, Shi X, Sinha KM, Loftus BJ, Cagney G and Bracken AP: Polycomb phf19 binds h3k36me3 and recruits prc2 and demethylase no66 to embryonic stem cell genes during differentiation. Nat Struct Mol Biol 19(12): 1273-1281, 2012. PMID: 23160351. DOI: 10.1038/nsmb.2449

11 Ge W, Wolf A, Feng T, Ho CH, Sekirnik R, Zayer A, Granatino N, Cockman ME, Loenarz C, Loik ND, Hardy AP, Claridge TDW, Hamed RB, Chowdhury R, Gong L, Robinson CV, Trudgian DC, Jiang M, Mackeen MM, McCullagh JS, Gordiyenko Y, Thalhammer A, Yamamoto A, Yang M, Liu-Yi P, Zhang Z, Schmidt-Zachmann M, Kessler BM, Ratcliffe PJ, Preston GM, Coleman ML and Schofield CJ: Oxygenasecatalyzed ribosome hydroxylation occurs in prokaryotes and humans. Nat Chem Biol 8(12): 960-962, 2012. PMID: 23103944. DOI: $10.1038 /$ nchembio. 1093

12 Chowdhury R, Sekirnik R, Brissett NC, Krojer T, Ho CH, Ng SS, Clifton IJ, Ge W, Kershaw NJ, Fox GC, Muniz JRC, Vollmar M, Phillips C, Pilka ES, Kavanagh KL, von Delft F, Oppermann U, McDonough MA, Doherty AJ and Schofield CJ: Ribosomal oxygenases are structurally conserved from prokaryotes to humans. Nature 510(7505): 422-426, 2014. PMID: 24814345. DOI: $10.1038 /$ nature 13263

13 Sun Y, Bell JL, Carter D, Gherardi S, Poulos RC, Milazzo G, Wong JW, Al-Awar R, Tee AE, Liu PY, Liu B, Atmadibrata B, Wong M, Trahair T, Zhao Q, Shohet JM, Haupt Y, Schulte JH, Brown PJ, Arrowsmith $\mathrm{CH}$, Vedadi M, MacKenzie KL, Huttelmaier S, Perini G, Marshall GM, Braithwaite A and Liu T: Wdr5 supports an n-myc transcriptional complex that drives a protumorigenic gene expression signature in neuroblastoma. Cancer Res 75(23): 5143-5154, 2015. PMID: 26471359. DOI: 10.1158/0008-5472.can-15-0423
14 Liu PY, Erriquez D, Marshall GM, Tee AE, Polly P, Wong M, Liu B, Bell JL, Zhang XD, Milazzo G, Cheung BB, Fox A, Swarbrick A, Huttelmaier S, Kavallaris M, Perini G, Mattick JS, Dinger ME and Liu T: Effects of a novel long noncoding rna, lncusmycn, on n-myc expression and neuroblastoma progression. J Natl Cancer Inst 106(7): pii: dju113, 2014. PMID: 24906397. DOI: $10.1093 /$ jnci/dju 113

15 Erdem-Eraslan L, Gravendeel LA, de Rooi J, Eilers PH, Idbaih A, Spliet WG, den Dunnen WF, Teepen JL, Wesseling P, Sillevis Smitt PA, Kros JM, Gorlia T, van den Bent MJ and French PJ: Intrinsic molecular subtypes of glioma are prognostic and predict benefit from adjuvant procarbazine, lomustine, and vincristine chemotherapy in combination with other prognostic factors in anaplastic oligodendroglial brain tumors: A report from eortc study 26951. J Clin Oncol 31(3): 328-336, 2013. PMID: 23269986. DOI: $10.1200 /$ jco.2012.44.1444

16 Gravendeel LA, Kouwenhoven MC, Gevaert O, de Rooi JJ, Stubbs AP, Duijm JE, Daemen A, Bleeker FE, Bralten LB, Kloosterhof NK, De Moor B, Eilers PH, van der Spek PJ, Kros JM, Sillevis Smitt PA, van den Bent MJ and French PJ: Intrinsic gene expression profiles of gliomas are a better predictor of survival than histology. Cancer Res 69(23): 9065-9072, 2009. PMID: 19920198. DOI: 10.1158/0008-5472.Can-09-2307

17 Brennan CW, Verhaak RG, McKenna A, Campos B, Noushmehr H, Salama SR, Zheng S, Chakravarty D, Sanborn JZ, Berman SH, Beroukhim R, Bernard B, Wu CJ, Genovese G, Shmulevich I, Barnholtz-Sloan J, Zou L, Vegesna R, Shukla SA, Ciriello G, Yung WK, Zhang W, Sougnez C, Mikkelsen T, Aldape K, Bigner DD, Van Meir EG, Prados M, Sloan A, Black KL, Eschbacher J, Finocchiaro G, Friedman W, Andrews DW, Guha A, Iacocca M, O’Neill BP, Foltz G, Myers J, Weisenberger DJ, Penny R, Kucherlapati R, Perou CM, Hayes DN, Gibbs R, Marra M, Mills GB, Lander E, Spellman P, Wilson R, Sander C, Weinstein J, Meyerson M, Gabriel S, Laird PW, Haussler D, Getz G and Chin L: The somatic genomic landscape of glioblastoma. Cell 155(2): 462-477, 2013. PMID: 24120142. DOI: 10.1016/j.cell.2013.09.034

18 Panosyan EH, Lin HJ, Koster J and Lasky JL, 3rd: In search of druggable targets for gbm amino acid metabolism. BMC Cancer 17(1): 162, 2017. PMID: 28245795. DOI: 10.1186/s12885-0173148-1

19 Kaplan EL and Meier P: Nonparametric estimation from incomplete observations. In: Breakthroughs in statistics. Kotz S and Johnson N (eds.). Springer New York, pp. 319-337, 1992. DOI: 10.1007/978-1-4612-4380-9_25

20 Furnari FB, Cloughesy TF, Cavenee WK and Mischel PS: Heterogeneity of epidermal growth factor receptor signalling networks in glioblastoma. Nat Rev Cancer 15(5): 302-310, 2015. PMID: 25855404. DOI: $10.1038 / \mathrm{nrc} 3918$

21 Wang X, Huang Z, Wu Q, Prager BC, Mack SC, Yang K, Kim LJY, Gimple RC, Shi Y, Lai S, Xie Q, Miller TE, Hubert CG, Song A, Dong Z, Zhou W, Fang X, Zhu Z, Mahadev V, Bao S and Rich JN: Myc-regulated mevalonate metabolism maintains brain tumor-initiating cells. Cancer Res 77(18): 4947-4960, 2017. PMID: 28729418. DOI: 10.1158/0008-5472.Can-17-0114

22 Sinha KM, Bagheri-Yarmand R, Lahiri S, Lu Y, Zhang M, Amra S, Rizvi Y, Wan X, Navone N, Ozpolat B, Logothetis C, Gagel RF and Huard J: Oncogenic and osteolytic functions of histone demethylase no66 in castration-resistant prostate cancer. Oncogene 38(25): 5038-5049, 2019. PMID: 30858546. DOI: 10.1038/s41388-019-0774-x 
23 Nishizawa Y, Nishida N, Konno M, Kawamoto K, Asai A, Koseki J, Takahashi H, Haraguchi N, Nishimura J, Hata T, Matsuda C, Mizushima T, Satoh T, Doki Y, Mori M and Ishii H: Clinical significance of histone demethylase no66 in invasive colorectal cancer. Ann Surg Oncol 24(3): 841-849, 2017. PMID: 27473587. DOI: $10.1245 / \mathrm{s} 10434-016-5395-9$

24 Mazzoleni S, Politi LS, Pala M, Cominelli M, Franzin A, Sergi Sergi L, Falini A, De Palma M, Bulfone A, Poliani PL and Galli R: Epidermal growth factor receptor expression identifies functionally and molecularly distinct tumor-initiating cells in human glioblastoma multiforme and is required for gliomagenesis. Cancer Res 70(19): 7500-7513, 2010. PMID: 20858720. DOI: 10.1158/0008-5472.Can-10-2353
25 Zheng H, Ying H, Yan H, Kimmelman AC, Hiller DJ, Chen AJ, Perry SR, Tonon G, Chu GC, Ding Z, Stommel JM, Dunn KL, Wiedemeyer R, You MJ, Brennan C, Wang YA, Ligon KL, Wong WH, Chin L and dePinho RA: Pten and p53 converge on c-myc to control differentiation, self-renewal, and transformation of normal and neoplastic stem cells in glioblastoma. Cold Spring Harb Symp Quant Biol 73: 427-437, 2008. PMID: 19150964. DOI: $10.1101 / \mathrm{sqb} .2008 .73 .047$

Received September 25, 2019

Revised October 9, 2019

Accepted October 10, 2019 